\title{
СРЕДСТВА ВИЗУАЛИЗАЦИИ ДОСТАВКИ ЛЕКАРСТВЕННЫХ ВЕЩЕСТВ С ИСПОЛЬЗОВАНИЕМ АНИОНИРОВАННЫХ ХИТОЗАНОВ
}

\author{
С.А. Захаренкова', М.И. Лебедева', А.Н. Лебедева', И.А. Дорошенко', \\ Г.Г. Кривцов ${ }^{2}$, А.А. Ежов ${ }^{3}$, Т.А. Подругина', М.К. Беклемишев \\ ${ }^{1}$ Химический факультет, Московский государственный университет \\ им. М.В. Ломоносова, 119991, Россия, г. Москва, Ленинские горы, д. 1, стр. 3. \\ ${ }^{2}$ Научно-исследовательский институт вакцин и сывороток им. И.И. Мечникова, \\ 105064, Россия, г. Москва, Малый Казенный пер., д. 5А. \\ ${ }^{3}$ Физический факультет, Московский государственный университет им. М.В. Ломоносова, \\ 119991, Россия, г. Москва, Ленинские горы, д. 1, стр. 2.
}

DOI: 10.19163/MedChemRussia2021-2021-432

E-mail: sophie.chaplenko@gmail.com

Наноструктуры различной природы широко используются для доставки лекарственных веществ в клетки и ткани. При этом биоразлагаемые материалы обладают неоспоримыми преимуществами в следствие их низкой токсичности. Хитозан является природным полисахаридом, производным хитина, и часто используется для получения самосборных наноконтейнеров для доставки [1].

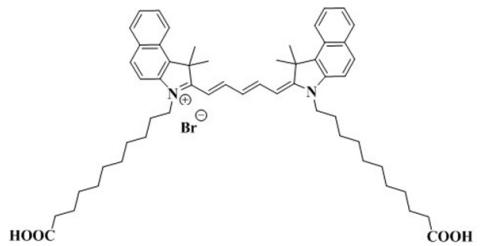

Мы использовали меченный родамином анионированный хитозан: карбоксиметилированный, малеинированный и сульфатированный. Хитозан образует комплексы (К) с флуоресцирующими тройными агрегатами доставляемое вещество - противоион - гидрофобный карбоцианиновый краситель

(см. структуру), обнаруженными нами ранее [2]. Обнаружено, что комплексы К, сшитые глутаровым альдегидом, устойчивы - время разрушения в режиме диализа составило более часа. Образование комплексов (К) подтверждено методами динамического и Рэлеевского рассеяния света.

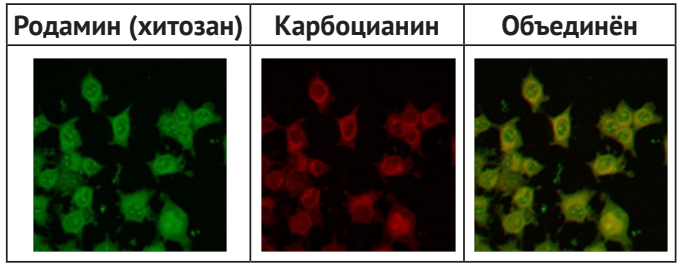

Работа выполнена при поддержке РФФИ (проект № 20-03-00334a).
Таким образом, мы показали проникновение комплексов К в клетки.В дальнейшем мы планируем доказать, что при этом комплекс К не разрушается, используя карбоцианин, который сам по себе не диффундирует через клеточные мембраны.

\section{References}

[1] P. Agrawal, G. J. Strijkers, K. Nicolay, Advanced Drug Delivery Reviews. 2010, 62, 42-58.

[2] S.A. Zakharenkova e.a. Spectr. Acta A, 2021, 247. DOI: 10.1016/j.saa.2020.119109. 